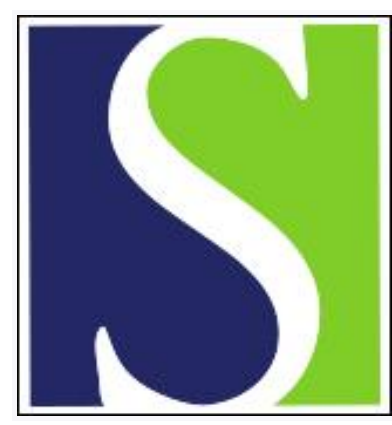

Scand J Work Environ Health 1994;20(6):407-416

https://doi.org/10.5271/sjweh.1380

Issue date: 01 Dec 1994

\section{Silica dust exposure and lung cancer.}

by Koskela RS, Klockars M, Laurent $H$, Holopainen M

Affiliation: Finnish Institute of Occupational Health, Helsinki.

This article in PubMed: www.ncbi.nlm.nih.gov/pubmed/7701286 


\title{
Silica dust exposure and lung cancer
}

\author{
by Riitta-Sisko Koskela, MSocSc, ${ }^{1}$ Matti Klockars, MD, ${ }^{1,2} \mathrm{H}$ Laurent, MD, ${ }^{1}$ M Holopainen, MD ${ }^{3}$
}

\begin{abstract}
KOSKELA R-S, KLOCKARS M, LAURENT H, HOLOPAINEN M. Silica dust exposure and lung cancer. Scand J Work Environ Health 1994;20:407-16.

ObJective - The study evaluated the possibility of a direct association between silica dust exposure and lung cancer.

METHODS - Mortality and morbidity among 1026 granite workers was followed in $1940-1989$. Regional census data for 1970-1985 and lung cancer incidence data were also linked. The cytotoxicity of different granite fractions and their capacity to induce reactive oxygen species (ROS) in human leukocytes was studied in vitro.

REsults - Excess lung cancer mortality was found during several follow-up periods. The rate ratios were 1.6-3.8 for different latency periods. Lung cancer risk increased with the length of exposure and latency. Lung cancer morbidity in 1953-1987 showed an excess for the red and grey granite areas, the rate ratio being 2.5 for $\geq 20$-year latency. Only one lung cancer case came from the black granite area. The cancer cases from the grey area had a shorter latency than those from the red area. The mineral composition differed for each area. The strongest ROS-inducing activity of grey and red granite was seen in the quartz-containing fractions. In the cytotoxicity tests the quartz-containing fractions of the grey and red granite also caused the strongest lactic dehydrogenase (LDH) release. However, plagioclase, the main constituent of black granite $(60 \%)$, had approximately the same ability to induce ROS as the quartz-containing fractions of red and grey granite.

Conclusions - The cancer morbidity and mortality figures of the three different granite areas, combined with the found differences in biological activity of granite dusts and a hypothesis that there is a cancer-inducing mechanism for ROS, point to a direct role for quartz in cancer induction.
\end{abstract}

KEY TERMS - cytotoxicity, lung cancer, morbidity, mortality, quartz, reactive oxygen species, silica.

The International Agency for Research on Cancer (IARC) concluded in June 1986 that there was sufficient evidence of carcinogenicity for crystalline silica in experimental animals, but the evidence was insufficient to show carcinogenicity in humans (1). In March 1987, IARC collected new epidemiologic information on carcinogenic risk from exposure to silica (2). There were still serious difficulties to interpret epidemiologic results based on different study populations varying in, for example, study design, cohort definition, period of exposure, follow-up, quality of data on exposure history, and so forth. (3). Neither of the following hypotheses could be verified exclusively: (i) exposure to silica is a direct cause of both silicosis and lung cancer and (ii) exposure to silica is an indirect cause of increased lung cancer risk through the development of silicosis, which would have a promoting effect on the carcinogenic process (2).

The pathogenesis of chronic lung disease induced by granite dust (including lung cancer) is dependent

I Finnish Institute of Occupational Health, Helsinki, Finland.

2 Department of Public Health, University of Helsinki, Helsinki, Finland.

3 National Public Health Institute, Kuopio, Finland.

Reprint requests to: Ms R-S Koskela, Finnish Institute of Occupational Health, Topeliuksenkatu 41 a A, FIN-00250 Helsinki, Finland. on the alveolar deposition of the dust. The role of silica-induced cytotoxicity, macrophage destruction, and the subsequent proliferative collagenous fibrosis for the possible development of lung cancer is not clear $(4,5)$. The host responses including immunologic factors related to long-term exposure to mineral dusts and the possible role of reactive oxygen species produced by inflammatory cells exposed to mineral particles have been suggested to play a role in carcinogenesis $(1,6,7)$.

The aim of the present study was to evaluate the possibility of a direct association between silica dust exposure and lung cancer.

The study included the cancer mortality and morbidity of a cohort of 1026 granite workers from 1940 to 1989 . In addition regional census data in 19701985 and lung cancer incidence data were linked. Second, in vitro biological cell tests were performed with mineral fractions of different granites.

\section{Epidemiologic studies on mortality and morbidity}

Study populations

The epidemiologic part of the study comprised the following two different study populations: (i) a cohort of 1026 Finnish granite workers employed in quarries and processing yards in three main granite 
areas of Finland and (ii) census-based target populations from the same three regions. The study was carried out stepwise according to the study designs presented in figure 1.

\section{Exposure}

Dust exposure was measured in the Finnish granite industry in 1970-1972 (8). The geometric mean of the total dust concentration ranged from 1.7 to $39.8 \mathrm{mg} \cdot \mathrm{m}^{3}$ and that of quartz dust from 1.0 to $1.5 \mathrm{mg} \cdot \mathrm{m}^{3}$. The highest concentrations were found in drilling, being about ten times the hygienic standard for quartz.

Complete occupational histories of the cohort members were obtained from the questionnaire carried out in 1986. Using dust measurements and lifelong exposure histories, an industrial hygienist estimated both the amount of total dust and quartz dust blindly for the cases and referents.

Confounding occupational exposure during a lifetime, as well as smoking, was checked through the questionnaire data and controlled in the data analysis.

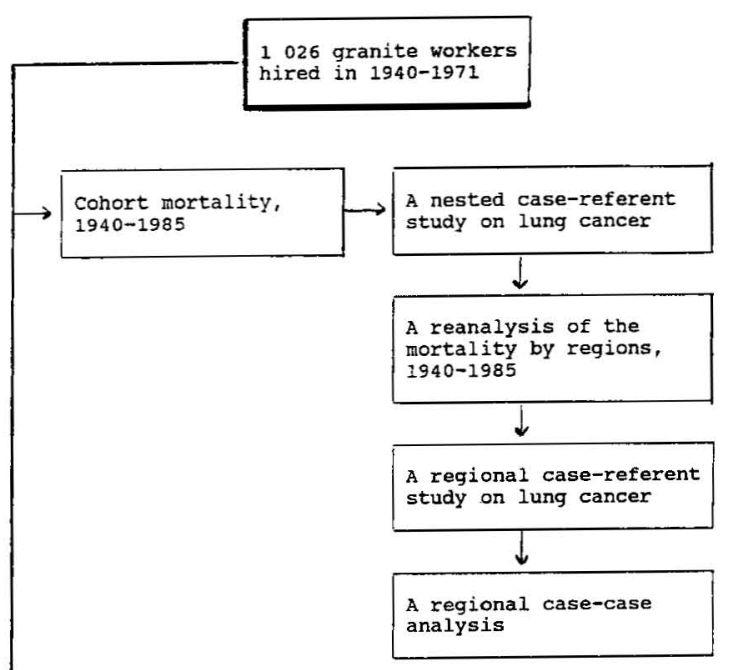

Mortality by regions 1940-1989

Lung cancer morbidity

by regions, 1953-1987

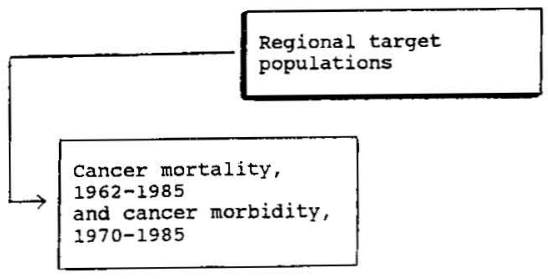

Figure 1. A flowchart of the study.
Cohort study on lung cancer mortality in 19401985

Material and methods. The cohort consisted of the workers who had started granite work between 1940 and 1971 and had worked for at least three months. The data on the subjects and their exposure histories were collected from the employers' personnel records and from the questionnaire carried out in 1986. The data on diagnosed diseases were obtained from the questionnaire and from medical records. The causes of death were ascertained from the death certificates.

The mortality of the cohort had been followed earlier in $1972(9), 1975(10), 1981(11,12)$, and 1985 (13). The present study was based on the results of a mortality study carried out in 1985 (13). The main results on cancer mortality in 1940-1985 can be briefly summarized as follows.

The expected numbers were based on the national figures for men in the median year of the deaths in the cohort (1975) (14). The age-specific observed numbers of deaths and the expected numbers of deaths according to national figures were computed for the different causes of death. The use of the median year was based on separate calculations for the median year of deaths and mortality rates specific for five-year calendar periods $(15,16)$. The difference between these calculations was negligible. The lung cancer mortality rates were also ascertained for this cohort of granite workers by computing the expected numbers first in parallel using the mortality rates specific for five-year calendar periods and the median year rates (12). The difference between the expected numbers based on the median-year calculation and the rates specific for calendar period ranged from 0.0 to 0.8 . The observed numbers were tested by means of the Poisson distribution model with the expected numbers (17).

Results. By the end of 1985,296 of the 1026 granite workers had died (table 1). The observed number of tumors was 59, and the expected number was 54.4. Of these, 31 were lung cancers [expected 19.9, standardized mortality ratio (SMR) $156,95 \%$ CI $106-$ 221]. Mortality from lung cancer was excessive for the workers followed for at least 15 years (observed 28 , expected 12.7, SMR $220,95 \%$ CI 147-319). Of the 40 deaths due to respiratory diseases, 13 were due to silicosis. Only three decedents had had both silicosis and lung cancer mentioned on the death certificate.

\section{Nested case-referent study on lung cancer}

Material and methods. All of the 31 lung cancer cases observed in the cohort as a primary cause of death were included in a nested case-referent study. Two referents (one living and one dead; the date of death had to be later than that of the case) without 
cancer were selected for each case. Both of the referents had to be of the same age ( \pm 2 years) and to have entered granite work at the same time ( \pm 4 years) as the case. The quality of information on lifetime exposure had to be similar for the case and referent. Lifelong (cumulative) quartz dust exposure (the sum of the length of exposure in each job title multiplied by the job-specific quartz dust concentrations during the corresponding calendar periods) was compared between the cases and referents.

Results. The 31 lung cancer cases were not more heavily exposed than their 62 matched pairs. The mean of the lifelong concentration of quartz dust was $14.4 \mathrm{mg} \cdot \mathrm{m}^{3}$ for the cases and $18.9 \mathrm{mg} \cdot \mathrm{m}^{3}$ for the referents. In the pair comparison only nine cases had a clearly higher exposure category than the individual referents. The mean length of exposure time was 19 years for the cases and 22 years for the referents. However, the cases and referents were distributed asymmetrically according to employer. Of the cases $48 \%$ came from workplaces from the Vehmaa region and $52 \%$ from the Kuru region, and none from the Viitasaari region. Of the referents $55 \%$ came from workplaces in the Vehmaa region, $40 \%$ from Kuru, and $5 \%$ from Viitasaari.

\section{Analysis of cohort mortality by regions}

Material and methods. Because of the asymmetry in the regional distribution of lung cancer cases and referents, the whole cohort was reanalyzed by regions so that the potential differences in regional lung cancer mortality could be determined. The statistical methods were the same as those used in the analysis of the whole cohort. (See the section Cohort Study on Lung Cancer in 1940-1985).

Results. The risk for lung cancer was 1.3-fold (SMR 126, 95\% CI 71-208) for the workers in
Vehmaa (observed 15, expected 11.9), and 2.1-fold (SMR 211, 95\% CI 120-342) for the workers in Kuru (observed 16, expected 7.6) in comparison with that of the general male population (table 1). No cancer cases, even other than lung cancer, were observed among the workers in Viitasaari. The agespecific smoking habits were similar in the three regional cohorts. There were no statistically significant differences even in the age-specific numbers of heavy smokers (on an average $\geq 20$ cigarettes a day).

In Vehmaa 10 of the 15 primary and 4 of the 5 secondary lung cancer cases occurred after at least 25 years of follow-up, whereas only 6 of the 17 lung cancer cases in the Kuru region had such a long latency (table 2).

The type of granite was Balmoral red in Vehmaa, grey in Kuru, and black in Viitasaari. The amount of quartz in the mineral was $36 \%$ in the Balmoral red of Vehmaa, $31 \%$ in the Kuru grey, and $0 \%$ in the Viitasaari black (table 3 ).

\section{Regional case-referent study on lung cancer}

Material and methods. A detailed analysis of lifelong granite dust exposure was made from the region-based case-referent study. Three in the case group had also been working in foundries or in welding; therefore they were excluded from this analysis because of the confounding exposure. Thus 28 cases ( 14 cases from Vehmaa and 14 from Kuru) and one referent (living or dead) matched for age ( \pm 4 years) and smoking for each case were selected for the region-based case-referent study.

Lifelong (cumulative) quartz dust exposure (calculated as in the section Nested Case-Referent Study on Lung Cancer) was compared between the cases and referents in the Vehmaa and Kuru regions (a case exposed more than its referent receiving + and a case exposed less than its referent receiving -). The two regional distributions of the + and - figures were

Table 1. Observed and expected numbers of certain causes of death for granite workers in the three regions of study and the whole cohort separately. The period of entry was defined as 1940-1971, and the period of follow-up as $1940-1985$.

\begin{tabular}{|c|c|c|c|c|c|c|c|c|}
\hline \multirow[t]{2}{*}{ Cause of death } & \multicolumn{2}{|c|}{$\begin{array}{c}\text { Vehmaa } \\
\text { (Balmoral red } \\
\text { granite) }\end{array}$} & \multicolumn{2}{|c|}{$\begin{array}{c}\text { Kuru } \\
\text { (grey granite) }\end{array}$} & \multicolumn{2}{|c|}{$\begin{array}{c}\text { Viitasaari } \\
\text { (black granite) }\end{array}$} & \multicolumn{2}{|c|}{ Whole cohort } \\
\hline & $\begin{array}{l}\text { Ob- } \\
\text { served }\end{array}$ & $\begin{array}{c}\text { Ex- } \\
\text { pected }\end{array}$ & $\begin{array}{l}\text { Ob- } \\
\text { served }\end{array}$ & $\begin{array}{l}\text { Ex- } \\
\text { pected }\end{array}$ & $\begin{array}{l}\text { Ob- } \\
\text { served }\end{array}$ & $\begin{array}{c}\text { Ex- } \\
\text { pected }\end{array}$ & $\begin{array}{l}\text { Ob- } \\
\text { served }\end{array}$ & $\begin{array}{c}\text { Ex- } \\
\text { pected }\end{array}$ \\
\hline All deaths & 150 & 161.2 & 137 & $105.0^{\star \star}$ & 9 & 9.9 & 296 & 276.2 \\
\hline Cardiovascular diseases & 68 & 79.1 & 58 & 52.1 & 2 & 3.9 & 128 & 135.0 \\
\hline Coronary heart disease & 38 & $55.8^{\star}$ & 39 & 36.6 & 2 & 2.6 & 79 & 95.0 \\
\hline Tumors & 27 & 32.1 & 32 & $20.8^{\star}$ & - & 1.5 & 59 & 54.4 \\
\hline $\begin{array}{l}\text { Lung cancer } \\
\text { Cancer of the }\end{array}$ & 15 & 11.9 & 16 & $7.6^{* *}$ & - & 0.4 & 31 & $19.9^{\star}$ \\
\hline digestive organs & 8 & 6.9 & 10 & $4.4^{\star}$ & - & 0.3 & 18 & 11.6 \\
\hline Respiratory diseases & 26 & $10.5^{\star * *}$ & 14 & $6.9^{*}$ & - & 0.5 & 40 & $17.8^{* * *}$ \\
\hline
\end{tabular}

${ }^{*} \mathrm{P}<0.05,{ }^{* *} \mathrm{P}<0.01,{ }^{* * *} \mathrm{P}<0.001$, Poisson distribution. 
Table 2. Observed and expected lung cancer deaths (1940-1985) according to years since entry into granite work (latency), as recorded in the employers' rolls. (SMR = standardized mortality ratio, $95 \% \mathrm{Cl}=95 \%$ confidence interval, $+=$ secondary cause)

\begin{tabular}{|c|c|c|c|c|c|c|c|c|c|c|}
\hline \multirow{2}{*}{$\begin{array}{l}\text { Latency } \\
\text { (years since } \\
\text { entry) }\end{array}$} & \multicolumn{5}{|c|}{$\begin{array}{c}\text { Vehmaa } \\
\text { Balmoral Red }\end{array}$} & \multicolumn{5}{|c|}{ Kuru grey } \\
\hline & $\begin{array}{l}\text { Ob- } \\
\text { served }\end{array}$ & $(+)^{\mathrm{a}}$ & $\begin{array}{c}\text { Ex- } \\
\text { pected }\end{array}$ & SMR & $95 \% \mathrm{Cl}$ & $\begin{array}{l}\text { Ob- } \\
\text { served }\end{array}$ & $(+)$ & $\begin{array}{c}\text { Ex- } \\
\text { pected }\end{array}$ & SMR & $95 \% \mathrm{Cl}$ \\
\hline $\begin{array}{l}\geq 10 \\
\geq 15 \\
\geq 20 \\
\geq 25 \\
\geq 30 \\
\geq 35\end{array}$ & $\begin{array}{r}15 \\
13 \\
11 \\
10 \\
5 \\
4\end{array}$ & $\begin{array}{l}(5) \\
(5) \\
(4) \\
(4) \\
(3) \\
\cdot\end{array}$ & $\begin{array}{l}9.5 \\
7.5 \\
5.2^{*} \\
3.3^{* *} \\
1.8^{\#} \\
0.9^{*}\end{array}$ & $\begin{array}{l}158 \\
173 \\
212 \\
303 \\
278 \\
444\end{array}$ & $\begin{array}{c}88-260 \\
92-296 \\
106-379 \\
145-557 \\
90-648 \\
121-1138\end{array}$ & $\begin{array}{r}16 \\
15 \\
9 \\
6 \\
2 \\
-\end{array}$ & $\begin{array}{l}(1) \\
(1) \\
(1) \\
\cdot \\
\cdot \\
\cdot\end{array}$ & $\begin{array}{l}6.1^{\star \star} \\
4.9^{\star \star \star} \\
3.6^{\star} \\
2.4 \\
1.2 \\
0.3\end{array}$ & $\begin{array}{r}262 \\
306 \\
250 \\
250 \\
167 \\
0\end{array}$ & $\begin{array}{r}150-426 \\
171-505 \\
114-475 \\
92-544 \\
20-602 \\
000-999\end{array}$ \\
\hline Total & 15 & (5) & 11.9 & 126 & $71-208$ & 16 & (1) & $7.6^{\star \star}$ & 211 & $120-342$ \\
\hline
\end{tabular}

a Secondary cause is included only for controlling potential differences in the rates caused by the standard classification system of the primary cause. No statistical analyses were based on the secondary causes.

$\# P \approx 0.05,{ }^{*} P<0.05,{ }^{* *} P<0.01,{ }^{\star \star *} P<0.001$, Poisson distribution.

Table 3. Mineral composition of the three types of granite.

\begin{tabular}{lccc}
\hline Mineral & \multicolumn{3}{c}{ Type of granite } \\
\cline { 2 - 4 } & $\begin{array}{c}\text { Balmoral red } \\
(\text { Vehmaa) } \\
(\%)\end{array}$ & $\begin{array}{c}\text { Grey } \\
(\text { Kuru }) \\
(\%)\end{array}$ & $\begin{array}{c}\text { Black } \\
(\text { Viitasaari }) \\
(\%)\end{array}$ \\
\hline Feldspar & 41 & 38 & 0 \\
Quartz & 36 & 31 & 0 \\
Plagioclase & 16 & 20 & 60 \\
Mica & 7 & 9 & 0 \\
Amphibole and & 0 & 2 & 0 \\
pyroxenes & 0 & 0 & 20 \\
Augite & 0 & 0 & 15 \\
Fluorite & 0 & 0 & 5 \\
Hornblende & 100 & 100 & 100 \\
\hline All & & &
\end{tabular}

Table 4. Comparison of lifelong quartz dust exposure between the case-referent series in the Kuru grey granite area and in the Vehmaa Balmoral red granite area.

\begin{tabular}{lcc}
\hline $\begin{array}{l}\text { Lifelong quartz } \\
\text { dust exposure }\end{array}$ & Kuru grey & $\begin{array}{c}\text { Vehmaa } \\
\text { Balmoral red }\end{array}$ \\
\hline Cases > Referents & 3 & 9 \\
Cases = Referents & 2 & 1 \\
Cases < Referents & 9 & 4 \\
\hline Total & 14 & 14 \\
\hline
\end{tabular}

a This group of equal exposure was omitted from the test. $\mathrm{X}^{2}=4.89, \mathrm{P}<0.05$, Kuru versus Vehmaa.

tested by the chi-square test for fourfold tables (17) (table 4).

Results. The analysis of lifelong granite dust exposure showed that the cases from Vehmaa were more exposed than their age- and smoking-matched referents, whereas the cases from Kuru were less exposed than their referents. The difference between these regional figures was statistically significant $\left(\mathrm{P}<0.05, \mathrm{X}^{2}\right.$ test $)$.

\section{Regional case-case analysis}

Material and methods. Differences in exposure were also analyzed between the Vehmaa and Kuru lung cancer cases (10 age-matched case-pairs).

Lifelong quartz dust exposure (calculated in the same way as in the preceding section) was compared between Kuru cases and Vehmaa cases with the aid of the Wilcoxon test for two samples (17).

Results. The comparison of the lifelong quartz dust exposure between the Vehmaa and Kuru lung cancer cases (10 age-matched case-pairs) showed that the cases from Kuru were statistically significantly less exposed than the cases from Vehmaa $(\mathrm{P}<0.01$, according to the Wilcoxon test).

\section{Follow-up of the cohort mortality by regions in 1940-1989}

Material and methods. The regional mortality results of the cohort were updated until the end of 1989. The calculations of the exposure and latency years were based on the complete occupational history obtained from the questionnaire in 1986. The expected numbers were based on the national figures for men in the median year of the deaths in the cohort (1977) (18). The observed numbers were tested against the expected numbers by the Poisson distribution model (17).

Results. By the end of 1989 the number of personyears was 26113 , and 363 deaths had been observed (332.1 expected) (ie, 67 deaths more than at the end of 1985) (table 5). Seventy-three of these deaths were due to cancer. The number of lung cancers was 36 (expected number 25.8 , SMR $140,95 \%$ CI 98-193). An analysis by region showed that 18 lung cancer deaths occurred in the Vehmaa red granite area (expected number 15.4, SMR 117, 95\% CI 69-185), 17 from the Kuru grey granite area 
Table 5. Observed and expected numbers of certain causes of death for the granite workers in the three regions separately and also for the whole cohort combined. The period of entry was defined as 1940-1971, and the period of follow-up as $1940-1989$.

\begin{tabular}{|c|c|c|c|c|c|c|c|c|}
\hline \multirow{2}{*}{ Cause of death } & \multicolumn{2}{|c|}{$\begin{array}{c}\text { Vehmaa } \\
\text { Balmoral red }\end{array}$} & \multicolumn{2}{|c|}{$\begin{array}{l}\text { Kuru } \\
\text { grey }\end{array}$} & \multicolumn{2}{|c|}{$\begin{array}{l}\text { Viitasaari } \\
\text { black }\end{array}$} & \multicolumn{2}{|c|}{ Whole cohort } \\
\hline & $\begin{array}{l}\text { Ob- } \\
\text { served }\end{array}$ & $\begin{array}{c}\text { Ex- } \\
\text { pected }\end{array}$ & $\begin{array}{l}\text { Ob- } \\
\text { served }\end{array}$ & $\begin{array}{c}\text { Ex- } \\
\text { pected }\end{array}$ & $\begin{array}{c}\text { Ob- } \\
\text { served }\end{array}$ & $\begin{array}{c}\text { Ex- } \\
\text { pected }\end{array}$ & $\begin{array}{c}\text { Ob- } \\
\text { served }\end{array}$ & $\begin{array}{c}\text { Ex- } \\
\text { pected }\end{array}$ \\
\hline All deaths & 191 & 195.8 & 160 & $123.4^{* * *}$ & 12 & 13.0 & 363 & $332.1^{*}$ \\
\hline Cardiovascular diseases & 89 & 102.3 & 70 & 64.8 & 3 & 5.5 & 162 & 172.6 \\
\hline Ischemic heart disease & 50 & 69.6 & 45 & 44.3 & 2 & 3.8 & 97 & 117.7 \\
\hline Tumors & 35 & 39.1 & 37 & $24.6^{\star \star}$ & 1 & 2.0 & 73 & 65.7 \\
\hline $\begin{array}{l}\text { Lung cancer } \\
\text { Cancer of the }\end{array}$ & 18 & 15.4 & 17 & $9.7^{*}$ & 1 & 0.7 & 36 & $25.8^{*}$ \\
\hline digestive organs & 8 & 8.5 & 11 & $5.3^{*}$ & - & 0.4 & 19 & 14.4 \\
\hline Respiratory diseases & 31 & $13.4^{* * *}$ & 16 & $8.4^{* *}$ & - & 0.6 & 47 & $22.3^{* * *}$ \\
\hline
\end{tabular}

${ }^{*} \mathrm{P}<0.05,{ }^{* *} \mathrm{P}<0.01,{ }^{* * *} \mathrm{P}<0.001$, Poisson distribution.

Table 6. Observed and expected lung cancer deaths by granite areas in 1940-1989 according to the length of exposure and latency, as based on the questionnaire.

\begin{tabular}{|c|c|c|c|c|c|c|}
\hline \multirow{3}{*}{ Area } & \multicolumn{6}{|c|}{ Latency (years) } \\
\hline & \multicolumn{2}{|c|}{$<20$} & \multicolumn{2}{|c|}{$\geq 20$} & \multicolumn{2}{|c|}{$\Sigma$} \\
\hline & Observed & Expected & Observed & Expected & Observed & Expected \\
\hline \multicolumn{7}{|c|}{ Vehmaa (Balmoral red granite) } \\
\hline $\begin{array}{l}<10 \text { years of exposure } \\
\geq 10 \text { years of exposure } \\
\Sigma\end{array}$ & $\begin{array}{l}1 \\
0 \\
1\end{array}$ & $\begin{array}{l}1.8 \\
1.1 \\
2.9\end{array}$ & $\begin{array}{r}4 \\
13 \\
17\end{array}$ & $\begin{array}{r}2.7 \\
9.8 \\
12.5\end{array}$ & $\begin{array}{r}5 \\
13 \\
18\end{array}$ & $\begin{array}{r}4.6 \\
10.9 \\
15.4\end{array}$ \\
\hline \multicolumn{7}{|l|}{ Kuru (grey granite) } \\
\hline $\begin{array}{l}<10 \text { years of exposure } \\
\geq 10 \text { years of exposure } \\
\Sigma\end{array}$ & $\begin{array}{l}1 \\
4 \\
5\end{array}$ & $\begin{array}{l}1.6 \\
0.6^{*} \\
2.2\end{array}$ & $\begin{array}{r}3 \\
9 \\
12\end{array}$ & $\begin{array}{l}2.5 \\
5.1 \\
7.5\end{array}$ & $\begin{array}{r}4 \\
13 \\
17\end{array}$ & $\begin{array}{l}4.1 \\
5.6^{* *} \\
9.7^{*}\end{array}$ \\
\hline \multicolumn{7}{|l|}{ Both } \\
\hline $\begin{array}{l}<10 \text { years of exposure } \\
\geq 10 \text { years of exposure } \\
\Sigma\end{array}$ & $\begin{array}{l}2 \\
4 \\
6\end{array}$ & $\begin{array}{l}3.4 \\
1.7 \\
5.1\end{array}$ & $\begin{array}{r}7 \\
22 \\
29\end{array}$ & $\begin{array}{l}5.2 \\
14.9^{\#} \\
20.1^{\star}\end{array}$ & $\begin{array}{r}9 \\
26 \\
35\end{array}$ & $\begin{array}{l}8.6 \\
16.5^{\star} \\
25.1^{\star}\end{array}$ \\
\hline
\end{tabular}

" $P \approx 0.05, * P<0.05, * * P<0.01$, Poisson distribution.

(9.7 expected, SMR 175, 95\% CI 102-281), and one from the Viitasaari black granite area $(0.7 \mathrm{ex}$ pected).

The risk for lung cancer increased as the years of exposure and latency increased (table 6). In the lower latency categories the rates were higher for the Kuru region than for the Vehmaa region.

\section{Lung cancer morbidity in the cohort} in 1953-1987.

Material and methods. The same cohort was followed for the study of cancer morbidity from the Finnish Cancer Register in the years 1953-1987. The observed numbers were compared with the corresponding national figures registered in the cancer register during the same period.

For the study of cancer morbidity in the cohort the expected numbers of primary cancers were calculated on the basis of national figures by five-year calendar periods. The observed age-specific and causespecific numbers of cancer cases were tested by the
Poisson distribution model (17) against the expected numbers.

Results. By the end of 1987, 43 lung cancers had occurred in the cohort, the expected number being 25.3 (SMR 170, 95\% CI 123-229). Twenty-five cases were from Vehmaa (15.4 expected, SMR 162, 95\% CI 105-240), 17 cases from Kuru (9.4 expected, SMR 181, 95\% CI 105-290), and only one case came from Viitasaari ( 0.5 expected). The lung cancer morbidity rates for Vehmaa and Kuru are shown in table 7. There was no statistically significant difference in the lung cancer incidence rates between the Vehmaa and Kuru regions, but the latency was shorter for Kuru (figure 2).

\section{Cancer mortality and morbidity in the target populations}

Material and methods. To confirm the results derived from the cohort study, we studied cancer mortality 
Table 7. Observed and expected morbidity from lung cancer in 1953-1987 according to years since entry into granite work (latency), as recorded in the employers' rolls. (SMR = standardized mortality ratio, $95 \% \mathrm{Cl}=95 \%$ confidence interval)

\begin{tabular}{|c|c|c|c|c|c|c|c|c|}
\hline \multirow{2}{*}{$\begin{array}{l}\text { Latency } \\
\text { (years since } \\
\text { entry) }\end{array}$} & \multicolumn{4}{|c|}{$\begin{array}{c}\text { Vehmaa } \\
\text { Balmoral red }\end{array}$} & \multicolumn{4}{|c|}{ Kuru grey } \\
\hline & Observed & Expected & SMR & $95 \% \mathrm{Cl}$ & Observed & Expected & SMR & $95 \% \mathrm{Cl}$ \\
\hline $\begin{array}{l}\geq 10 \\
\geq 15 \\
\geq 20 \\
\geq 25 \\
\geq 30\end{array}$ & $\begin{array}{r}25 \\
19 \\
17 \\
13 \\
9\end{array}$ & $\begin{array}{c}12.3^{* \star} \\
9.8^{\star \star} \\
6.9^{\star \star \star} \\
4.4^{\star \star \star} \\
2.4^{\star \star \star}\end{array}$ & $\begin{array}{l}203 \\
194 \\
246 \\
295 \\
375\end{array}$ & $\begin{array}{l}132-300 \\
117-303 \\
144-394 \\
157-505 \\
171-712\end{array}$ & $\begin{array}{r}17 \\
15 \\
11 \\
6 \\
3\end{array}$ & $\begin{array}{l}7.8^{* *} \\
6.4^{* *} \\
4.8^{\star} \\
3.2 \\
1.8\end{array}$ & $\begin{array}{l}218 \\
234 \\
229 \\
188 \\
167\end{array}$ & $\begin{array}{r}127-349 \\
131-387 \\
114-410 \\
69-408 \\
34-487\end{array}$ \\
\hline Total & 25 & $15.4^{\star}$ & 162 & $105-240$ & 17 & $9.4^{*}$ & 181 & $105-290$ \\
\hline
\end{tabular}

${ }^{\star} P<0.05,{ }^{* \star} P<0.01,{ }^{* \star *} P<0.001$, Poisson distribution.

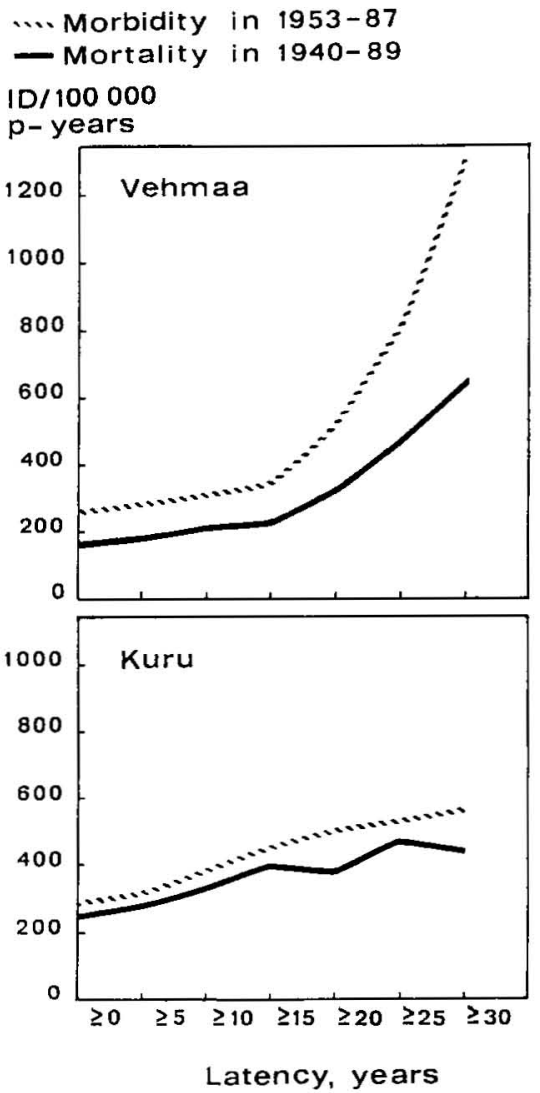

Figure 2. Age-standardized lung cancer mortality rates (1940-1989) and morbidity rates (1953-1987) in the cohort of the granite workers (expressed as incidence rates $1 / 100000)$. The exposure and latency calculations have been based on the employers' rolls. (ID = incidence density, p-years $=$ person-years)

Table 8. Age-specific cancer mortality for the total male population of Vehmaa, Kuru and Viitasaari in 1962-1985.

\begin{tabular}{lcccc}
\hline \multirow{2}{*}{ Region } & \multicolumn{4}{c}{ Incidence rates/100 000 person-years } \\
\cline { 2 - 5 } & $\begin{array}{l}45 \text { - to } 54- \\
\text { year-olds }\end{array}$ & $\begin{array}{c}55-\text { to } 64- \\
\text { year-olds }\end{array}$ & $\begin{array}{c}65 \text { - to } 74- \\
\text { year-olds }\end{array}$ & $\begin{array}{c}\geq 75 \text {-year- } \\
\text { olds }\end{array}$ \\
\hline Vehmaa & 251 & 643 & 1384 & 1312 \\
Kuru & 281 & 486 & 819 & 2358 \\
Viitasaari & 294 & 578 & 908 & 1852 \\
\hline
\end{tabular}

and morbidity in the regional target populations. The source material of the Finnish regional age- and cause-specific cancer mortality statistics (from Statistics Finland) were analyzed from 1962 to 1985. We studied the morbidity from lung cancer by linking the regional census data (from Statistics Finland) from the years $1970,1975,1980$, and 1985 and the lung cancer incidence data (from the Finnish Cancer Registry) for the period of 1970-1985. The incidences were compared between granite workers and workers in other occupations. The classification of occupations was based on the census data.

The differences in the age-specific cancer mortality and morbidity rates between the regional target populations were tested with the Mantel-Haenszel chi-square test for incidence data (19).

Results. The Finnish regional mortality statistics were studied from 1962 to 1985 . The age-specific cancer mortality rates for Viitasaari were similar to those for Kuru and Vehmaa (table 8).

In the regional study on lung cancer morbidity the regional census data from the years 1970, 1975, 1980, and 1985 and the lung cancer incidence data for the period of $1970-1985$ were linked. The cancer incidence rate for the red-granite workers was statistically significantly higher than that for the remaining male population in that area (figure 3). The same was true for the grey-granite workers. The blackgranite workers, however, did not have an excess lung cancer incidence (only two cases among the exposed).

\section{Discussion}

Excess mortality from lung cancer has been repeatedly observed in this cohort of granite workers exposed to pure silica. Similarly the cancer morbidity study showed an excess risk for lung cancer. The workers had long periods of exposure to granite dust [mean 12 (range $0-49$ ) years]. The period of follow-up (1940-1989) was 50 years (variation $18-50$ years). The risk for lung cancer increased with the length of exposure and growing years of latency. 


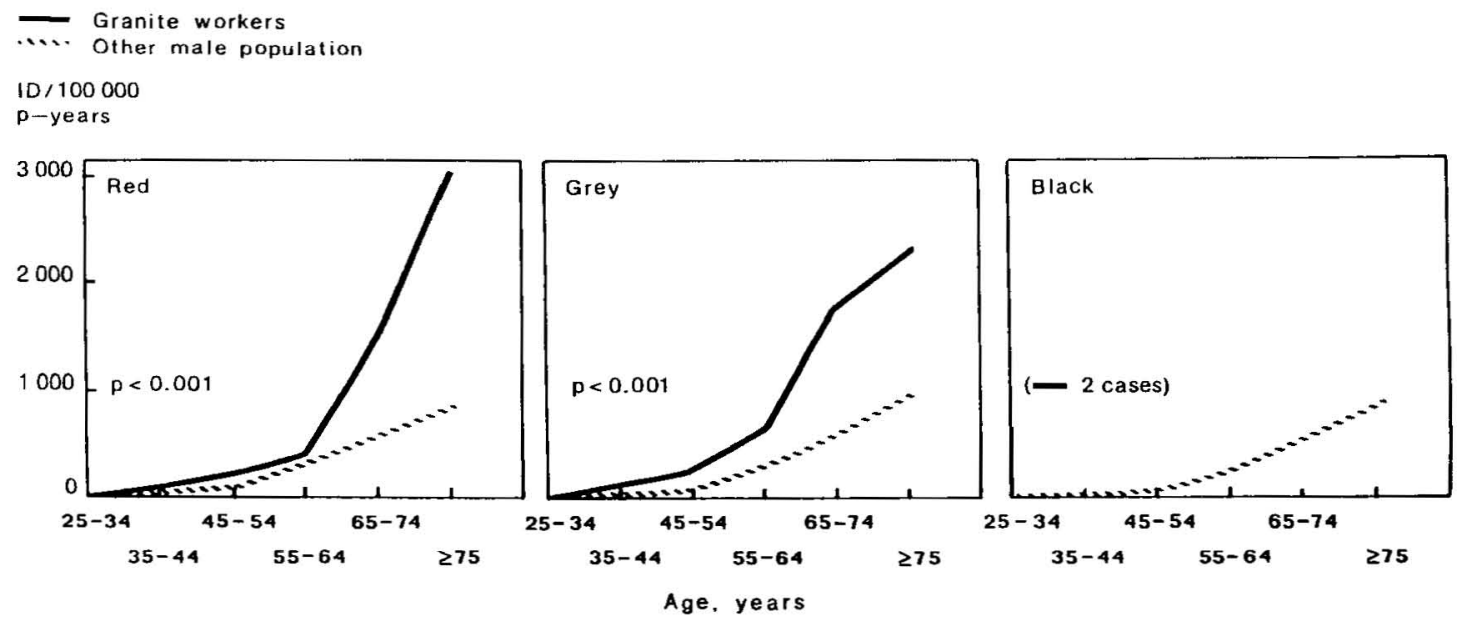

Figure 3. Lung cancer incidence rates for the granite workers of the three granite areas and among the remaining regional male populations in 1970-1985 (census data). (ID = incidence density, p-years = person-years)

Excess lung cancer mortality and morbidity was found among the workers finishing quartz-containing granite (Vehmaa Balmoral red and Kuru grey). The black granite in Viitasaari did not contain any quartz. However, the subcohort of blackgranite workers was too small to give evidence of a hypothetically lower cancer risk in this quartz-free area.

The granite workers had no remarkable exposure history to potential concomitant carcinogens (13). Neither did smoking alone explain the excess risk for lung cancer. The smoking habits of the granite workers were similar to those of other Finnish male workers. No essential differences were observed in the smoking habits between the regional subcohorts, not even in the number of heavy smokers.

Methodological modifiers (eg, variation in the years of entry into the cohort) may have affected the occurrence of cancer and other latency-dependent diseases. This possibility has been thoroughly discussed earlier (13). The effect of structural differences in the regional subcohorts was further controlled in the present study.

The cohort was restricted to include only workers who entered granite work in 1962 at the earliest (the year from which the data were identically available from all the workplaces). Both the lung cancer morbidity and mortality remained highest for the grey-granite subcohort.

The mean exposure time was 7.3 years for the black-granite workers and about four years longer for the red- and grey-granite workers. On the other hand, $73 \%$ of the black-granite workers had a latency of at least 24 years; $55 \%$ of all the lung cancer cases in the red- and grey-granite subcohorts occurred within 24 years.

Shorter lifelong exposure times, as well as shorter periods of latency for lung cancer, were observed for the grey-granite workers in Kuru. The physico- chemical composition of the dusts (size, particle surface characteristics, adsorption features, etc) $(5,7$, 20) may explain the regional differences in both the risk of lung cancer and the latency.

Because the subcohort of the black-granite area in Viitasaari was very small, all available additional material was obtained, and further internal analyses were made for the cohort.

The study on the Finnish regional mortality statistics showed that the age-specific cancer mortality rates for Viitasaari were similar to those for Kuru and Vehmaa. Thus our result did not depend on the fewer cancer cases in one of the target populations, namely, in the black-granite area.

The analysis of lung cancer morbidity in the regional census material gave results similar to those of the cohort study. Consequently, the black-granite workers who had been excluded from our cohort did not show an increased risk for lung cancer.

Because of the small sample size, a potential lung cancer risk may occur later in the black granite area among the persons not included in our cohort, especially among persons with silicosis. Therefore, the Finnish Register of Occupational Diseases in 19641991 was checked for the black granite area. Altogether 13 occupational diseases were found; only two of them were silicosis.

The prevalences of self-reported diagnosed cardiovascular diseases and diagnosed musculoskeletal diseases, except rheumatoid arthritis, were similar in all of the subcohorts. Of the 45 cases of rheumatoid arthritis observed in the whole cohort, 22 originated from Vehmaa, 13 from Kuru, and none from Viitasaari. The prevalences of diagnosed pneumonia, bronchitis, and bronchial asthma were similar in the subcohorts. The prevalences of diagnosed lung tuberculosis, pleurisy, emphysema, and silicosis were clearly lower in the black-granite subcohort, than in the red- and grey-granite subcohorts. These low prev- 
alences of chronic lung diseases and rheumatoid arthritis among the black-granite workers were ascertained from the medical records. The low prevalence of chronic lung diseases and rheumatoid arthritis suggests a different disease-generating potential for the quartz-free black granite $(13,21)$.

The co-occurrence of lung cancer and pulmonary silicosis was rare. In the mortality data for 1940 1989 four lung cancer cases also had a diagnosis of silicosis mentioned on the death certificate or in the disability register. Altogether 37 cases of silicosis were recorded on the death certificate or in the disability register for the whole cohort of 1026 granite workers; only eight of them had lung cancer. The age-standardized incidence rate (SIR) (ID/100 000) was similar for the cohort members with diagnosed silicosis (SIR 209) and for those without diagnosed silicosis (SIR 192), and similar even for those with a minimum latency of 20 years (being 258 and 220 , respectively). Among the 37 silicotic patients 31 cases of silicosis originated from Vehmaa $(31 / 579=$ $5.4 \%$ ), eight having lung cancer, and six came from Kuru $(6 / 340=1.8 \%)$, one having lung cancer.

Increased mortality from gastrointestinal cancers $(12,13)$ and excess morbidity from certain nonmalignant disease patterns (eg, rheumatoid arthritis) (11, 21) were observed in the earlier follow-ups. Inhalation of organic and inorganic material will also cause a variety of immediate systemic consequences. Deposition of dusts within the respiratory tract, local and systemic immunologic responses, toxic reactions, decreased resistance to infectious diseases, or translocation of foreign material may explain such increased nonrespiratory morbidity $(22-24)$.

The following results of the present study and the earlier follow-ups support the hypothesis that silica per se influences the development of lung cancer: (i) excess morbidity and mortality from lung cancer among the workers exposed to pure silica, (ii) increased cancer risk for the workers finishing quartzcontaining granite, (iii) long periods of exposure to quartz, (iv) long periods of follow-up and the latency dependency of the disease, (v) no remarkable concomitant carcinogens (confounding exposures and methodological modifiers being controlled), (vi) cooccurrence of lung cancer and silicosis rare, (vii) increased mortality from cancer of extra pulmonary sites (gastrointestinal cancers), and (viii) excess morbidity from rheumatoid arthritis.

\section{In vitro experiments with fractionated dusts of red, grey, and black granite}

The inflammatory and carcinogenic potential of mineral dusts has been linked to the feature of dusts to cause cytotoxicity or to generate reactive oxygen species in their target tissues (6). With two tests we studied the proinflammatory differences between dust samples of red, grey, and black granite in vitro.

\section{Material and methods}

Mineral dusts were obtained from the different granite samples by grinding, particles with various densities were separated by liquid density separation, and the minerals contained in the density fractions $(<2.63,2.63-2.75$, and $>2.75)$ were determined for the red, grey, and black granite. The Kuru grey granite was $80 \%$ feldspar, $<20 \%$ quartz and some biotite in the density fraction of $<2.63 ; 70 \%$ quartz, $25 \%$ feldspar, and $<5 \%$ biotite in the $2.63-2.75$ density fraction; and $>90 \%$ biotite and $<5 \%$ feldspar in the $>2.75$ density fraction. Of the particles, 59 $76 \%$ had a diameter of less than $10 \mu \mathrm{m}$. The Vehmaa red granite was $<90 \%$ feldspar and $<10 \%$ quartz in the density fraction of $<2.63 ;>75 \%$ quartz, $<25 \%$ feldspar, and $<2 \%$ biotite in the $2.63-2.75$ density fraction; and $>85 \%$ biotite, $<10 \%$ feldspar, and $<5 \%$ quartz in the $>2.75$ density fraction. Some $64-74 \%$ of the particles had a diameter of less than $10 \mu \mathrm{m}$. The Viitasaari black granite contained practically no material with a density fraction of $<2.63$; in the density fraction of $2.63-2.75$ it was predominantly plagioclase; and in the density fraction of $>2.75$ it was augite, enstatite, and biotite. Of the particles, 74$82 \%$ had a diameter of less than $10 \mu \mathrm{m}$.

The mineral fractions were analyzed for their cytotoxic potential, lactic dehydrogenase (LDH) release of rat macrophages in the presence of $1 \mathrm{mg} \cdot \mathrm{ml}^{-1}$ of dust (25), and their capacity to generate reactive oxygen species in human polymorphonuclear leukocytes with a chemiluminescent method (26).

\section{Results}

Ground and unfractionated black-, grey-, and redgranite dusts induced the production of reactive oxygen species. The peak chemiluminescent responses were 46.3 (SD 17.0) $\mathrm{mV}(\mathrm{N}=9)$ for black granite, 46.2 (SD 12.1) $\mathrm{mV}(\mathrm{N}=8)$ for grey granite, and 30.8 (SD 11.1) $\mathrm{mV}(\mathrm{n}=9)$ for red granite.

In the cytotoxicity tests the quartz-containing fractions (density $2.63-2.75$ ) of grey and red granite caused the strongest LDH release (figure 4). The differences between the fractions were, however, small.

In their capacity to induce the production of reactive oxygen species in human polymorphonuclear leukocytes, the strongest activity of grey and red granite was also seen in the quartz-containing fractions (density 2.63-2.75) (figure 5). However, similar reactive oxygen species production was also seen with the quartz-free fraction of black granite. This activity was caused by the almost pure plagioclase fraction. Compared with the activity of quartz, the activity of $100 \mu \mathrm{g} \cdot \mathrm{ml}^{-1}$ granite-dust fractions corresponded to $25-50 \mu \mathrm{g} \cdot \mathrm{ml}^{-1}$ of purified DQ-quartz (figure 5).

\section{Discussion}

No consistent pattern of biological responses (ie, cytotoxicity or activity inducing reactive oxygen spe- 


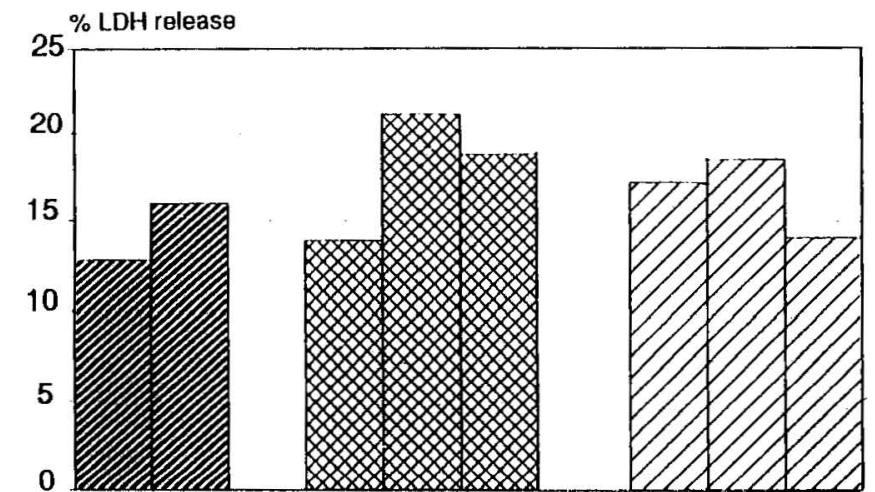

Black $<2.75$

Grey $<2.63$

$2.63-2.75$

Red $<2.63$

$>2.75$

$>2.75$

2.63-2.75

\section{$>2.75$}

Granite fraction
Figure 4. Cytotoxicity percentage (\%LDH release) caused by different fractions of black, grey and red granite. (LDH = lactic dehydrogenase) cies) could be observed for the different granites and their mineral fractions. The quartz-containing fractions of granite seemed to be the most active component. This finding may be related to in vivo consequences, and it is in keeping with (or does not contradict) the epidemiologic findings from the quartzcontaining grey and red granite areas. That these in vitro biological responses could be related to the epidemiology of cancer in the quartz-free black granite area must so far be considered purely speculative. Although the quartz-free fractions of the black granite were less cytotoxic than the corresponding fractions of the red and grey granite, the membrane effects, as measured by the generation of reactive oxygen species, were very similar. This activity corresponded to the presence of plagioclase. The in vivo effects of plagioclase (calcium-containing feldspar) are not known. The inflammatory and carcinogenic potential of various inhaled dusts have been related to pulmonary deposition, the surface characteristics of the particles, interaction with biological membranes, and possibly with their capacity to adsorb chemical carcinogens.

The relationship between the present epidemiologic and experimental results must, naturally, be interpreted with caution, but nevertheless it indicates new directions for the study of regional respiratory morbidity.

\section{Acknowledgments}

We express our warmest thanks to M Koponen, $\mathrm{PhD}$, for his help with the estimation of lifelong quartz exposures, to $\mathrm{P}$ Sotka, $\mathrm{MScGeol}$, for his preparation and analysis of the dust samples, and to J Mustala, $\mathrm{PhL}$, for his expert advice in mineralogy. We wish to thank E Järvinen, MSc, for his statistical advice,

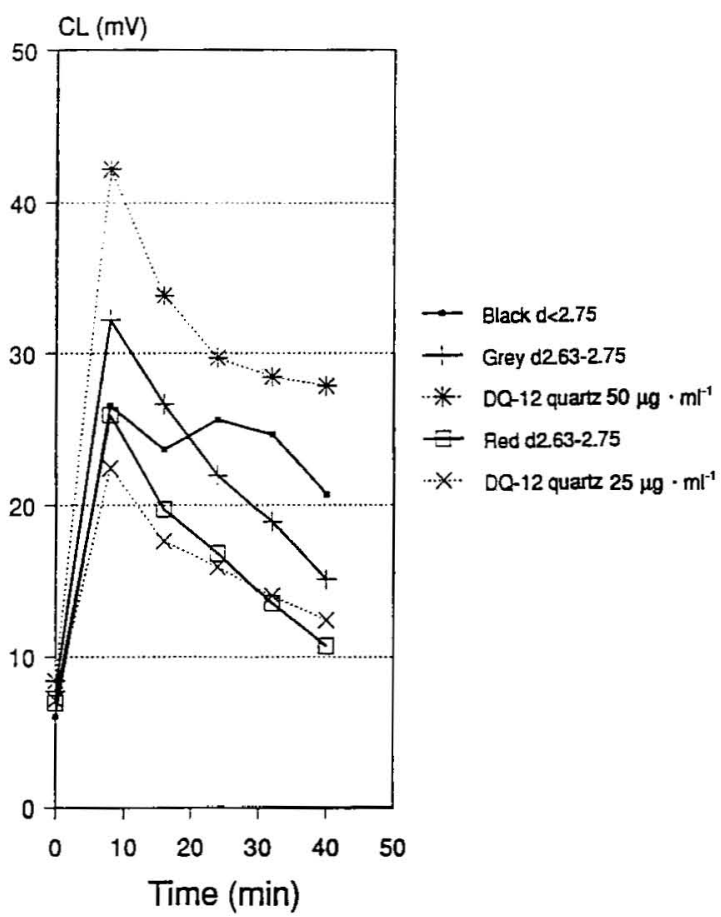

Figure 5. Responses of reactive oxygen species in human polymorphonuclear leukocytes exposed to different mineral fractions $\left(100 \mathrm{mg} \cdot \mathrm{ml}^{-1}\right)$ of black, grey, and red granite. (CL $=$ chemiluminescent method, $d=$ density fraction)

J-A Sorsa, BSc, and S Simonen, BSc, for the data processing, and Ms R Lukinmaa for gathering and coding the data. The register-based data were obtained from the Finnish Cancer Registry, from Statistics Finland, from the Finnish Register of Occupational Diseases (Finnish Institute of Occupational Health), and from the Population Register Centre. 
We want to thank them all. Data on medical records were collected with the permission of the Ministry of Health and Social Affairs. We also thank the hospitals and health care stations for these records.

\section{References}

1. International Agency for Research on Cancer (IARC) Silica and some silicates. Lyon: IARC, 1987. IARC monographs on the evaluation of the carcinogenic risk chemicals to humans, vol 42 .

2. Simonato L, Fletcher AC, Saracci R, Thomas TL, editors. Occupational exposure to silica and cancer risk. Lyon: International Agency for Research on Cancer (IARC), 1990. IARC scientific publications, no 97.

3. Pairon JC, Brochard P, Jaurand MC, Bignon J. Silica and lung cancer: a controversial issue: review. Eur Respir J 1991;4:730-44.

4. Heppleston AG. Pulmonary toxicology of silica, coal and asbestos. Environ Health Perspect 1984;55:11127.

5. Silicosis and Silicate Disease Committee. Diseases associated with exposure to silica and nonfibrous silicate minerals. Arch Pathol Lab Med 1988;112:673720.

6. Mossman BT, Light W, Wei E. Asbestos: mechanisms of toxicity and carcinogenicity in the respiratory tract. Annu Rev Pharmacol Toxicol 1983;23:594-615.

7. Langer AM, Nolan RP. Physicochemical properties of quartz controlling biological activity. In: Goldsmith DF, Win DM, Shy CM, editors. Silica silicosis and lung cancer: controversy in occupational medicine. New York, NY: Praeger, 1986:125-35. Cancer research monographs, vol 2.

8. Ahlman K, Backman AL, Hannunkari I, Järvinen E, Koponen E, Koskela R-S, et al. Kivityöntekijöiden työolosuhteet ja terveydentila [Work conditions and health of granite workers]. Helsinki: Kansaneläkelaitos, 1975. Kansaneläkelaitoksen julkaisuja AL:4/1975. (English summary).

9. Koskela R-S, Järvinen E. Mortality, disability and health among granite workers. In: Ahlman K, Backman A-L, Hannunkari I, Järvinen E, Koponen M, Koskela R-S, et al. Kivityöntekijöiden työolosuhteet ja terveydentila [work conditions and health of granite workers]. Helsinki: Kansaneläkelaitos, 1975:89-117. Kansaneläkelaitoksen julkaisuja AL:4/1975.

10. Kurppa K, Koskela R-S, Gudbergsson H. Gastrointestinal cancer in workers exposed to quartz. Lancet $1982 ; 1: 150$

11. Koskela R-S, Klockars M, Järvinen E, Kolari PJ, Rossi A. Mortality and disability among granite workers. Scand J Work Environ Health 1987;13:18-25.

12. Koskela R-S, Klockars M, Järvinen E, Kolari PJ, Rossi
A. Cancer mortality of granite workers. Scand J Work Environ Health 1987;13:26-31.

13. Koskela R-S, Klockars M, Järvinen E, Rossi A, Kolari PJ. Cancer mortality of granite workers 1940-1985. In: Simonato L, Fletcher AC, Saracci R, Thomas TL, editors. Occupational exposure to silica and cancer risk. Lyon: International Agency for Research on Cancer (IARC), 1990:43-53. IARC scientific publications, no 97.

14. World Health Organization (WHO). World health statistics annual 1975; vol 1 (Vital statistics and causes of death). Geneva: WHO, 1979.

15. Koskela R-S, Järvinen E, Kolari PJ. Effect of cohort definition and follow-up length on occupational mortality rates. Scand J Work Environ Health 1984;10: $311-16$.

16. Tola S, Koskela R-S, Hernberg S, Järvinen E. Lung cancer mortality among iron foundry workers. J Occup Med 1979;21:753-60.

17. Lentner $C$, editor. Geigy scientific tables: vol. 2. 8 th ed. Basel: Ciba-Geigy Limited, 1982.

18. World Health Organization (WHO). World health statistics annual 1977; vol. I (Vital statistics and causes of death). Geneva: WHO, 1981

19. Rothman KJ, Boice JD Jr. Epidemiologic analysis with a programmable calculator. Boston, MA: Epidemiology Resources Inc, 1982.

20. Kuhn DC, Demers ML. Influence of mineral dust surface chemistry on eicosanoid production by the alveolar macrophage. J Toxicol Environ Health 1992;35: $39-50$.

21. Klockars M, Koskela R-S, Järvinen E, Kolari PJ, Rossi A. Silica exposure and rheumatoid arthritis: a followup study of granite workers 1940-81. Br Med J 1987; 294:997-1000.

22. Bailey WC, Brown M, Buechner HA, Weill H, Ichinose $\mathrm{H}$, Ziskind M. Silico-mycobacterial in sandblasters. Am Rev Respir Dis 1974;110:115-25.

23. Burrell R. Immunological aspects of coal workers' pneumoconiosis. Ann NY Acad Sci 1982;200:94 105.

24. Harmsen AG, Muggenburg BA, Snipes MD, Bice DE The role of macrophages in particle translocation from lungs to lymph nodes. Science 1985;230:1277-80.

25. Pasanen JT, Gustafsson TE, Kalliomäki P-L, Tossavainen A, Järvisalo JO. Cytotoxic effects of four types of welding fumes on macrophages in vitro; a comparative study. J Toxicol Environ Health 1986;18:14352.

26. Hedenborg M, Klockars M. Quartz dust-induced production of reactive oxygen metabolites by human granulocytes. Lung 1989;167:23-32.

Received for publication: 11 March 1994 